Note

\title{
On student reflective portfolios in honors education
}

Merel van Goch ${ }^{1 *}$

1. Assistant professor, Liberal Arts and Sciences, Institute for Cultural Inquiry; and Departmental Coordinator School Liberal Arts, Humanities Honours Programme, Utrecht University, The Netherlands

*Correspondence: M.M.vanGoch@uu.nl

Received: 22 April 2018, Accepted: 30 April 2018, Published: 23 May 2018

Keywords: reflective portfolio; honors education; undergraduate education

\section{Reflective portfolios in higher education}

This note describes the use of portfolio reflections in undergraduate honors education to foster and assess the development of students throughout their honors education and their regular program. Reflection can be defined as: "a cognitive and affective process or activity that (1) requires active engagement on the part of the individual; (2) is triggered by an unusual or perplexing situation or experience; (3) involves examining one's own responses, beliefs, and premises in light of the situation at hand; and (4) results in integration of the new understanding into one's experience" (Rogers, 2001, p. 41). When used in higher education, reflections - or reflective essays - are usually bundled in portfolios. Students commonly reflect on their education and development at set times, and reflections are typically assessed formatively, although summative evaluation is possible. Since people construct meaning "in the space between their experiences and their reactions to the experiences" (Kegan, 1982, p. 2), reflective portfolios can be very helpful for students in navigating their experiences in higher education. Two important reasons why programs should implement the use of reflective portfolios in their curricula are (1) to assist students to make connections and (2) to foster self-understanding and meta-cognitive skills (Landis, Scott, \& Kahn, 2015).

Students' development throughout their education, which students reflect on in their portfolios and which therefore plays an important role in the literature on reflective portfolios, can be linked to self-authorship: "an ideology, an internal identity, a selfauthorship that can coordinate, integrate, act upon, or invent values, beliefs, convictions, generalizations, ideals, abstractions, interpersonal loyalties, and intrapersonal states. It is no longer authored by them, it authors them and thereby achieves a personal authority" (Kegan, 1994, p. 185, italics in original). Three aspects of development are unified in selfauthorship theory (Kegan, 1994): 
- epistemological development, which encompasses "how people use assumptions about the nature, limits, and certainty of knowledge to decide what to believe," leading to students who "integrate disparate information to make decisions" (Baxter Magolda \& King, 2007)

- intrapersonal development, which concerns "how people construct their identities," leading to students who "explore, reflect on, and internally choose enduring values to form their identities, and use this internal identity to interpret and guide their experiences and actions" (Baxter Magolda \& King, 2007)

- interpersonal development, which describes how people form "mature relationships that require respect for both self and other," leading to students who "have the developmental capacity for interdependence, or the ability to respect one's own and others' needs, negotiate multiple perspectives, and engage in genuinely mutual relationships" (Baxter Magolda \& King, 2007)

Baxter Magolda and King (2007) summarize that "self-authorship on all three dimensions reflects the integrated developmental capacities that are inherent in the cognitive, identity, and relational maturity required for college graduates to be effective workers, parents, family members, and citizens" (p. 492).

Yancey (2004) posed that there are actually multiple curricula at hand when talking about higher education: "the delivered curriculum of the classroom, the experienced curriculum as students receive and practice the delivered curriculum, and the lived curriculum as students learn over time from all sources in and beyond the classroom." (in Landis, Scott, \& Kahn, 2015, p. 108).

Reflective portfolios offer an excellent way for students to document their journey across these curricula and for teachers to follow and, where necessary, guide students on their journey (Landis, Scott, \& Kahn, 2015). For an example - and results - of how an interdisciplinary curriculum fosters self-authorship characteristics through their reflective portfolios, see Van der Lecq, 2016.

\section{Reflective portfolios in honors education}

Honors education typically provides extra opportunities to talented students (Wolfensberger, 2015). Most honors programs offer students ample opportunity to explore their talents and interests in a meaningful and often rather autonomous way. Reflective portfolios present a means for students to document their development of the three aspects of self-authorship (Kegan, 1994) through the three different curricula in higher education (Yancey, 2004) and - as important - for teachers to follow and guide students on that journey. As such, students can reflect on or make connections between:

- the different courses in their honors education

- their honors education versus their regular education

- their education versus their career

- their education versus their personal life

Since honors education can be experimental for staff as well, an additional benefit is that teachers are directly confronted by how students learn. Indeed, Landis, Scott, and Kahn (2015) found that teachers "noted direct benefits for themselves and their projects from improved understanding of their own curricula as they 'closed the loop' on their assessment and reflected ever more deeply on their own teaching practice" (p. 117). Although, in our 
case, the portfolio is not used to assess the effectiveness of courses or the curriculum, this is - according to Banta (2003) - possible. Another benefit for staff is that the portfolio aids archiving because students add 'evidence' of their honors education to their reflections.

\section{Reflective portfolio in Utrecht University's Humanities Honours Programme}

At the Humanities Honours Programme of Utrecht University, The Netherlands, students keep a written portfolio in which they reflect at least three times:

- at the start of the Honours Programme, which is the second year of their undergraduate education

- at the end of the first year of the Honours Programme

- at the end of the two-year Honours Programme, which coincides with their undergraduate graduation.

Students set goals, reflect on the goals, and look ahead. These reflections are supported by course results, projects, essays, and other evidence. The portfolio is usually a digital pdfformat for ease of archiving. Students are free to personalize the portfolio by adding illustrations, posters (e.g., of lectures or workshops they have organized as part of their honors education) and pictures (e.g., of international study trips or their thesis defense). By looking back and looking ahead at fixed moments in their curriculum, the portfolio forms a continuing element in students' study careers. After handing in their written portfolio reflections, students have a one-to-one conversation with their departmental honors coordinator to discuss the reflections and their academic and personal development. Students are assessed formatively, and they do not receive credits for the portfolio. A "sufficient" portfolio is, however, a prerequisite for finishing the honors program and obtaining the certificate.

Students are prompted to write about specific aspects about the program. These prompts guide students' development through their education and entail the following features:

- at the start of the honors program, students are asked - in approximately 250 words each - to (1) introduce themselves by explaining their background, why they applied for the honors program, and what extracurricular activities they are involved in, and (2) make a study plan for the coming year, elaborating on which regular and which honors courses they are planning to take, what their learning goals are, whether they are looking for academic depth, interdisciplinary breadth, or a bridge with society. Evidence they are asked to attach includes their motivation letter for the honors program and their CV

- at the end of the first honors year (which is the second year of their undergraduate program), students are asked - in approximately 500 words for (1) and 250 words for (2) - to (1) reflect on their first honors year, including how they feel about the past year, which courses they took, what they learned, what they are proud of, what they would have liked to have done better, how they contributed to the honors community, and whether they reached the goals they set at the beginning of the year, and (2) make a study plan for the next year, similar to how they did at the start of the honors program. As evidence, they include an overview of their course results and reports and projects of honors courses they produced

- at the end of the second year of the honors program (which is also graduation), students are asked - in approximately 500 words each - to (1) reflect on the past year in the same way as they did at the end of the first honors year and (2) to reflect 
on their participation in the honors program and their regular undergraduate program, including a description of how they look back on their education and a comparison of honors and regular undergraduate education, whether the expectations they had at the beginning of the program were met, and how they view their future. Included evidence again contains an overview of course results and reports and projects of honors courses, including their honors thesis.

\section{References}

Banta, T. W. (Ed.). (2003). Portfolio assessment: Uses, cases, scoring, and impact: Assessment update collections. San Francisco, CA: Jossey-Bass.

Baxter Magolda, M. B., \& King, P. M. (2007). Interview strategies for assessing selfauthorship: Constructing conversations to assess meaning making. Journal of College Student Development, 48(5), 491-508.

Kegan, R. (1982). The evolving self: Problem and process in human development. Cambridge, MA: Harvard University Press.

Kegan, R. (1994). In over our heads: The mental demands of modern life. Cambridge, MA: Harvard University Press.

Landis, C. M., Scott, S. B., \& Kahn, S. (2015). Examining the Role of Reflection in ePortfolios: A Case Study. International Journal of ePortfolio, 5(2), 107-121.

Rogers, R. R. (2001). Reflection in higher education: A concept analysis. Innovative Higher Education, 26(1), 37-57.

Van der Lecq, R. (2016). Self-Authorship Characteristics of Learners in the Context of an Interdisciplinary Curriculum: Evidence from Reflections. Issues in Interdisciplinary Studies, 34, 79-108.

Wolfensberger, M. V. C. (2015). Talent development in European higher education. Honors Programs in the Benelux, Nordic and German-Speaking Countries. Heidelberg: Springer. http://link.springer.com/book/10.1007\%2F978-3-319-12919-8

Yancey, K. B. (2004). Teaching Literature as Reflective Practice. Urbana, IL: National Council of Teachers of English. 